\title{
ON SOME VOCABULARY CHARACTERISTICS OF THE GOSPEL TRANSLATION BY K. POBEDONOSTSEV
}

\author{
Elena E. Remorova
}

Novosibirsk State University, Novosibirsk, Russia

\begin{abstract}
The article is devoted to a lexical analysis of the New Testament translation into Russian performed by an established statespersonKonstantin Pobedonostsev (1827-1907) at the beginning of the $20^{\text {th }}$ century. The lexical particularities of it have been revealed by means of its lexical comparison with the Synodal translation and the Church-Slavonic liturgical version. According to academic interpretation of the data collected the author stated that Konstantin Pobedonostsev's translationpreservesmore resemblance to the Church-Slavonic liturgical version, as there are 185 wordsinhis work, which were not found in the Synodal translation, but were used in Church-Slavonic liturgical version. The major part of the words is registered in lexicographical sources and reflects language norms of Pobedonostsev's lifetime. However, the smaller part is registered in the Russian Language National Corpus as being presented in the texts of the 1820-1920 period. The vocabulary specificity of the translation version under study lies in vast references to the Church-Slavonic liturgical version word pool. This fact is explained by stylistic preferences of the Gospel translators as well as by the target addressee image (people who are well informed about the orthodox liturgical tradition). In conclusion the author states that in his translation Konstantin Pobedonostsev never took words from the Church-Slavonic texts without prolonged meditation, the replacement cases seem to be an intentional choice of the words that were frequently used in the speech of his epoch.

Key words: New Testament, New Testament translation, Konstantin Pobedonostsev, vocabulary, ChurchSlavonic language, the Synodal translation, Slavonism.

Citation. Remorova E.E. On Some Vocabulary Characteristics of the Gospel Translation by K. Pobedonostsev. Vestnik Volgogradskogo gosudarstvennogo universiteta. Seriya 2, Yazykoznanie [Science Journal of Volgograd State University. Linguistics], 2017, vol. 16, no. 4, pp. 78-88. (in Russian). DOI: https://doi.org/10.15688/jvolsu2.2017.4.6
\end{abstract}

УДК 81 '25:811.163.1

Дата поступления статьи: 22.05.2017

ББК 81.18

Дата принятия статьи: 04.09.2017

\section{ЕВАНГЕЛЬСКИЙ ПЕРЕВОД К.П. ПОБЕДОНОСЦЕВА: О НЕКОТОРЫХ ОСОБЕННОСТЯХ СЛОВАРНОГО СОСТАВА}

\author{
Елена Ефимовна Реморова \\ Новосибирский государственный университет, г. Новосибирск, Россия
}

\begin{abstract}
Аннотация. Статья посвящена лексическому анализу перевода Нового Завета на русский язык, выполненного в начале XX в. известным государственным деятелем К.П. Победоносцевым (1827-1907). Лексические особенности перевода выявлены посредством сопоставления исследуемого труда с Синодальным пере으으 и церковнославянским богослужебным текстом. В результате обнаружены 183 слова, сохраненные 궁 Победоносцевым из церковнославянского текста и отличающие данный перевод от Синодального. Установцено, что большинство таких слов зафиксированы в лексикографических источниках, отражающих современный автору перевода языковой срез, другие отмечены в текстах XIX - первой половины XX в., представленных в Национальном корпусе русского языка. Спецификой словарного состава изучаемого перевода является широкое использование лексики литургического церковнославянского текста. Данная особенность определяется как стилистическими воззрениями автора на язык русского перевода евангелия, так и целевой () аудиторией перевода (люди, хорошо знакомые с православной богослужебной традицией). При этом, как
\end{abstract}


показало исследование, Победоносцев не переносит церковнославянские слова в текст перевода механически, а производит их тщательный отбор и использует, как правило, те лексемы, которые были употребительны в определенных текстах его эпохи.

Ключевые слова: Новый Завет, перевод Нового Завета, К.П. Победоносцев, лексика, церковнославянский язык, Синодальный перевод, церковнославянизм.

Цитирование. Реморова Е. Е. Евангельский перевод К.П. Победоносцева: о некоторых особенностях словарного состава // Вестник Волгоградского государственного университета. Серия 2, Языкознание. 2017. - T. 16, № 4. - C. 78-88. - DOI: https://doi.org/10.15688/jvolsu2.2017.4.6

\section{1}

Константин Петрович Победоносцев (1827-1907) - известный государственный деятель своего времени, ученый-правовед, воспитатель, а затем и ближайший советник императоров Александра III и Николая II, публицист, обер-прокурор Святейшего Синода (18801905). Кроме того, он известен как плодотворный литератор и переводчик [Глинский, 2004, с. 19]. Опубликованный в 1876 г. Синодальный перевод (далее - СП), работа над которым велась с 1816 г., по мнению Победоносцева, как «первый опыт ... не мог быть совершенным» и нуждался в уточнениях [Победоносцев, 2000, с. II]. В 1892 г. Победоносцев инициировал редактирование СП, разослав в духовные академии письмо с соответствующим предложением [Победоносцев, 1892, с. 1129-1130]. Фундаментальным трудом, появившимся в результате развернутого Победоносцевым мероприятия по усовершенствованию СП, стали «Замечания на Четвероевангелия» Н.Н. Глубоковского [Глубоковский, 1892]. Кроме того, при участии Победоносцева в 1893 г. были опубликованы материалы, содержащие комментированную редакторскую правку к СП митрополита Филарета (Дроздова) [Реморов, 2003, с. 4], а в 1895 г. в Берлине по инициативе Победоносцева был издан перевод Нового Завета, выполненный в 1844-1845 гг. В.А. Жуковским [Долгушин, 2008, с. 442]. Создание и публикацию в 1906 г. собственного варианта перевода Нового Завета можно назвать логичным завершением инициированного Победоносцевым мероприятия по пересмотру и доработке СП, итоговым трудом всей жизни автора ${ }^{1}$.

Перевод К.П. Победоносцева (далее ПКП) содержит предисловие, в котором излагаются переводческие принципы и обозначаются основные требования автора к языку Священного Писания. Открывается предисловие следующим утверждением: «Наш церковнославянский язык - великое сокровище нашего духа, драгоценный источник и вдохновитель нашей родной речи. Сила его, выразительность, глубина мысли, в нем отражающейся, гармония его созвучий и построения всей речи - создают красоту его, неподражаемую <...> Признано однако нужным иметь русский перевод Евангелия, и сделан первый опыт (имеется в виду СП - E. P.), который, по трудности этого дела, конечно, не мог быть совершенным. Необходимо продолжать эти опыты, доколе мы не получим перевод на языке, достойном славянского подлинника...» [Победоносцев, 2000, c. I-II]. Решение поставленной задачи автор видит в максимальном сближении русского текста с церковнославянским, поэтому при работе над созданием перевода Победоносцев, исходя от Синодального текста, изменяет его, насколько это возможно, в сторону церковнославянского. Основной принцип, согласно которому Победоносцев отбирает лексику для языка своего перевода, также сформулирован автором в предисловии: «Напрасно во многих случаях избегать в русском переводе славянских слов и речений, когда они в известном тоне употребительны в русской речи и всем понятны. <..> Во множестве случаев нет никакой нужды в этой замене, от которой речь нисколько не становится понятнее, а только вульгаризуется» [Победоносцев, 2000, с. III-IV].

Для рассмотрения того, как указанный подход воплощен на лексическом уровне рассматриваемого перевода, нами был проведен сопоставительный анализ Четвероевангелия в переводе Победоносцева с СП и церковнославянским текстом. Кроме того, все слова, сохраненные в ПКП из церковнославянского текста, мы проанализировали с точки зрения их фиксации в лексикографических источниках, отражающих лексическую систему русского языка эпохи Победоносцева, и в Национальном корпусе русско- 
го языка (Мы использовали тексты основного и поэтического подкорпусов, относящиеся к периоду 1820-х - 1920-х гг.). Представим основные результаты данного исследования.

\section{2}

Сопоставительный анализ источников свидетельствуюет о том, что К.П. Победоносцев славянизирует текст в двух направлениях: с одной стороны, он сохраняет многие церковнославянские слова, которые в СП переданы русским аналогом, а с другой - увеличивает частоту употребления тех заимствованных из церковнославянского текста слов, которые употребляются и в СП. Приведем характерные примеры:

Мф 25, 13; Лк 12, 37,39 бдеть ${ }^{2}$ (СП бодрствовать); Лк 14, 18; 24, 33 вкупе (СП все, вместе); Мф 27, 64 горше (СП хуже); Мф 5, 12; 10, 10 мзда (СП награда); Лк 24, 4; Мк 5, 28 риза (СП одежда); Мф 8, 18; Мк 3, 32 окрест (СП около); Мф 25, 33, 41; 27, 38 ошуюю (СП по левую сторону); Ин 1, 2; 8, 44 искони ${ }^{3}$ (СП (от, с) начала); Мк 16, 18 храмина (СП дом); Мк 16, 18 недужный (СП больной).

Всего методом сплошной выборки в ПКП нами было выявлено 183 лексемы, сохраненные из церковнославянского текста и отличающие исследуемый перевод от СП.
Такие слова мы считаем церковнославянизмами, руководствуясь терминологическим определением Г.О. Винокура: «Все то, что в каждую данную эпоху для говорящих и пишущих есть специальная принадлежность церковнославянского языка своего времени и в этом качестве способно функционировать как наделенный определенными стилистическими свойствами церковнославянский вариант общеупотребительного средства русской речи, и есть славянизм в стилистическом смысле слова» [Винокур, 2010, с. 163-164].

Следует сказать, что плотность таких слов в ПКП достаточно высока, так как многие церковнославянизмы употребляются в тексте не один раз: например, слово блюсти встречается 19 раз, владыка -18, востать $^{4}-50$, не обинуясь - 4, простирать (руку) - 10, некий - 22 и т. д. В таблице представлены наиболее характерные случаи, когда церковнославянизм используется и в СП, и в ПКП, с различием лишь в частоте употребления.

\section{3}

Среди лексем, сохраненных Победоносцевым из церковнославянского текста и отличающих данный текст от СП (наличием или частотностью), можно выделить несколько пластов, в зависимости от их отражения и характе-

Количество употребления славянизмов в ПКП и СП

\begin{tabular}{|c|c|c|c|c|}
\hline Славянизм & $\begin{array}{c}\text { Количество } \\
\text { употреблений } \\
\text { в ПКП } \\
\end{array}$ & $\begin{array}{l}\text { Некоторые } \\
\text { контексты }\end{array}$ & $\begin{array}{c}\text { Кол ичество } \\
\text { употреблений } \\
\text { в СП } \\
\end{array}$ & $\begin{array}{l}\text { Некоторые } \\
\text { контексты }\end{array}$ \\
\hline (со)творить & 132 & $\begin{array}{l}\text { Мф 25, 40; } \\
\text { Лк } 12,47\end{array}$ & 58 & $\begin{array}{l}\text { Мф 6, 2; } \\
\text { Ин 14, } 23\end{array}$ \\
\hline (у)разуметь & 78 & $\begin{array}{l}\text { Мф 12, 14; } \\
\text { Ин 10,6 }\end{array}$ & 35 & $\begin{array}{l}\text { Лк } 8,10 ; \\
\text { Ин } 17,7 \\
\end{array}$ \\
\hline приступить & 49 & $\begin{array}{l}\text { Мф 8, 18; } \\
\text { Лк } 12,37\end{array}$ & 29 & $\begin{array}{l}\text { Мф 26, 17; } \\
\text { Мк 6, 35 }\end{array}$ \\
\hline ведать & 48 & $\begin{array}{l}\text { Мф 6, 3; } \\
\text { Лк } 12,30\end{array}$ & 2 & $\begin{array}{l}\text { Мф 24, 43; } \\
\text { Лк 12, } 39\end{array}$ \\
\hline иные & 39 & Ин 10, 21 & 14 & $\begin{array}{l}\text { Мф 15, 30; } \\
\text { Ин 9, } 9\end{array}$ \\
\hline недуг & 17 & $\begin{array}{l}\text { Мф 4, 23; 9, 35; } \\
\text { Мк } 3,15 ; \\
\text { Лк 5, } 15\end{array}$ & 2 & $\begin{array}{l}\text { Лк 7,21; } \\
13,12\end{array}$ \\
\hline облекаться & 13 & $\begin{array}{l}\text { Мф 3, 4; } \\
\text { Лк 12, } 27\end{array}$ & 2 & $\begin{array}{l}\text { Мк } 16,5 ; \\
\text { Лк } 24,49\end{array}$ \\
\hline (вос)помянуть & 10 & Мф 27, 63 & 1 & Лк 1,54 \\
\hline повергнуть & 10 & Мф 27, 5 & 1 & Лк 4, 35 \\
\hline возбранить & 8 & Лк 6, 29 & 3 & $\begin{array}{l}\text { Мф 19, 13; } \\
\text { Лк } 18,15\end{array}$ \\
\hline
\end{tabular}


ристики в лексикографических источниках, представляющих современный Победоносцеву языковой срез. Наиболее подходящим для исследуемого нами материала по объему, системе помет и временным рамкам мы считаем «Толковый словарь русского языка» под редакцией проф. Д.Н. Ушакова (далее - СУ). Несмотря на то, что словарь был издан полностью в 1940 году, работа над ним велась, начиная с 1928 г., и, по утверждению авторов, основной объем словаря - «слова нашей классической литературы от Пушкина до Горького и общепринятого научного, делового и книжного языка, сложившегося в течение XIX века» (СУ, т. I, с. 3 первой пагинации). Итак, СУ мы считаем основным лексикографическим источником, подходящим для исследуемого материала. В качестве дополнительных источников мы использовали «Словарь языка Пушкина» и «Словарь церковнославянского и русского языка...» 1847 года.

3.1. К первому пласту мы относим те слова, сохраненные в ПКП из церковнославянского текста, которые присутствуют в СУ. Таких слов большинство (126 из 183), и их сопровождают пометы, «указывающие на разновидность письменной речи» и устанавливающие их «историческую перспективу» (СУ, т. I, c. XXVII второй пагинации): (книжн.), (поэт.), (церк-книжн.), (устар.), (старин.). В предисловии к СУ дается объяснение для каждой из указанных помет:

- (книжн.), книжное - «свойственно преимущественно книжному языку; употребленное в разговорной речи, все же сохраняет отпечаток книжности»;

- (поэт.), поэтическое - «свойственное поэзии»;

- (церк.-книжн.), церковно-книжное «слово является пережитком той эпохи, когда церковнославянская стихия преобладала в русском литературном языке»;

- (устар.), устарелое - «вышедшее или выходящее из употребления, но еще широко известное, между прочим, по классическим литературным произведениям XIX века»;

- (старин.), старинное - «слово является пережитком отдаленных эпох истории русского языка, но употребляется иногда авторами с какой-нибудь нарочитой стилистической целью» (СУ, т. I, с. XXVII-XXVIII второй пагинации).
Кроме того, в СУ представлены и собственно стилистические пометы, указывающие на «выразительные оттенки слов», среди которых пометы (ритор.) («употребительное только в стиле риторическом») и (торж.) («употребительное только в торжественном стиле») (СУ, т. I, с. XXVIII второй пагинации). Несмотря на отмечаемую исследователями нестройность в системе помет СУ [Емельянова, 2003, с. 445], в словаре дана подробная информация о каждой лексеме, необходимая для интерпретации рассматриваемого нами материала. Приведем некоторые характерные примеры из ПКП, распределив их в соответствии с лингвостилистической характеристикой, представленной в СУ (в скобках указано общее количество слов с конкретной пометой, употребленное в ПКП).

Книжные (20): Мф 27, 60 великий (СП большой); Мф 12, 8 владыка (СП господин); Лк 5, 11 извлечь (СП вытащить); Мф 27, 63 льстец (СП обманщик); Ин 10, 24 не обинуясь(я) (СП прямо); Лк 12, 16 некий (СП один); Мф 6, 25 печься (СП заботиться); Мк 3, 5 простирать (руку) (СП протянуть (руку)); Ин 14, 18 сирые (СП сироты); Мф 14, 10 усекнуть (СП отсечь).

Устаревшие (14): Мф 27, 64 горие (СП хуже); Мф 11, 12 доселе (СП доныне); Лк 5, 21 оставлять (грехи) (СП прощать); Мф 6,14 отпускать (СП прощать); Лк 5, 33; Мф 9, 14 почто (СП почему); Лк 7, 7 (из)речь (СП сказать); Лк 7, 45 (об)лобызать (СП (по)человать); Лк 23, 48 позор (СП зрелище); Лк 23, 54 пяток (СП пятница); Мф 22, 25 скляница (СП чама).

Устаревшие риторические и поэтические (6): Мф 8, 34 в сретение (СП навстречу); Лк 5, 37 изольется (СП вытечет); Лк 9, 17 кошница (СП короб); Лк 24, 4 риза (СП одежда); Мф 7, 28 словеса (СП слова); Мф 21, 33 столn (СП башня).

Книжно-устаревшие (31): Лк 12, 39 бдеть (СП бодрствовать); Лк 14, 18 вкупе (СП все, вместе); Мф 15, 9 всуе (СП тиетно); Ин 10, 41 знамение (СП чудо); Мф 5, 12 мзда (СП награда); Мф 10, 34 мнить (СП думать); Мк 16, 18 недужный (СП больной); Мф 3, 4 снедь (СП пища); Мф 10, 9 сребро (СП серебро); Лк 12, 58 (по)тщиться (СП (по)стараться).

Книжно-устаревшие риторические, поэтические, торжественные (16): Мф 3, 11 грясти (СП идти); Мф 9, 20 жена (СП женщина); Ин 9, 11 наречь (СП назвать); Мк 3, 32 окрест (СП около); Ин 10, 3 отверзать (СП отворять); Мф 27, 58 по- 
велеть (СП приказать); Мф 12, 44 празден (СП незанятый); Ин 10, 18 приять (СП получить); Мк 4, 32 сень (СП тень).

Книжно-старинные (2): Мф 25, 34 одесную (СП по правую сторону), Мф 25, 33 ошуюю (СП по левую сторону).

Церковно-книжные устаревшие и старинные (8): Мф 23, 6 вечеря (СП пиршество); Мф 6, 7 многоглаголание (СП многословие); Мф 10, 37 паче (СП более); Мф 7, 16 терния (СП терновник); Мф 11, 16 торжище (СП улица); Мф11, 19 чада (СП дети); Ин 11, 41 горем (СП на небо); Мф 6,11 днесь (СП на сей день).

Церковно-книжные устаревшие поэтические и риторические (18): Лк 14, 31 брань (СП война); Мф 10, 30 власы (СП волосы); Ин 21, 8 влачить (СП тащчить); Мф 4, 4 глагол (СП слово); Мф 10, 23 град (СПгород); Мф 6, 3 десница (СП правая рука); Мф 2, 11 злато (СП золото); Мф 5, 39 ланита (СП щека); Лк 18, 13 перси (СП грудь); Лк 12, 10 речет (СП скажет).

Старинные (10): Ин 7, 42 весь (в значении «село») (СП участок земли); Мк 6, 27 спекулатор (СП оруженосеи); Ин 10, 8 тать (СП вор); Ин 19, 19 титла (СП надпись); Мф 10, 42 токмо (СП только); Мф 27, 54 убояться (СП устрашиться); Лк 19, 20 убрус (СП платок); Мк 14, 12 уготовать (СП приготовить).

Приведенные примеры не означают, что Победоносцев всегда использовал на месте нейтрального слова стилистически маркированное. В его переводе встречаются и те, и другие слова, но маркированный вариант обычно более частотен в ПКП, чем нейтральный. В качестве примера приведем некоторые пары слов, указывая частоту их употребления в тексте исследуемого перевода:

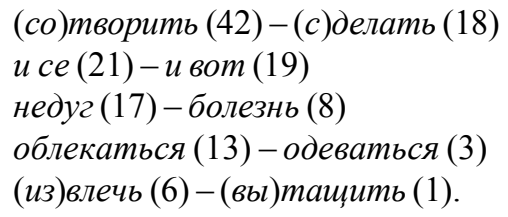

В большинстве контекстов для подобных пар слов нельзя выделить какой-либо тенденции употребления того или иного варианта. Использование разных лексем делает язык перевода более разнообразным и во многих отрывках помогает избежать тавтологии. Однако в некоторых случаях прослеживается четкая закономерность использования марки- рованной / немаркированной лексемы в зависимости от контекста. Например, слово делать употребляется, как правило, в устойчивом вопросительном словосочетании что делать (Мк 11, 3 Что вы делаете?; Ин 6, 28; Ин 11, 47 Что нам делать?), в остальных случаях обычно используется глагол творить (Мк 3, 4 достойно ли в субботу добро творить..?; Мф 5, 46 и мыттари не то же ли творят?). Частица се обычно употребляется в повествовании о Христе, чудесах, ангелах (Мф 28, 9; Лк 24, 51); частица вот вводит повествование о слепых (Мф 20, 30), прокаженных (Мф 8, 2), законниках (Лк 10, 25) и об обычных земных вещах (Лк 8,41 ; Лк 14,2 ).

Собранный материал свидетельствует о том, что основной особенностью словарного состава исследуемого перевода является широкое использование церковнославянизмов, которые выполняют стилистическую функцию. Тот факт, что все приведенные примеры отражены в СУ, свидетельствует о том, что Победоносцев не просто механически переносит в свой перевод церковнославянские слова, но выбирает те из них, которые употреблялись в определенном стиле языка его эпохи и были понятны современникам.

3.2. Второй пласт, меньший по объему (42 из 183), составляют сохраненные из церковнославянского текста лексемы, которые отсутствуют в СУ. Некоторые из них зафиксированы в «Словаре языка Пушкина»: среmuть, предать (в значении «передать»), отселе, кольми паче, внити, одеянный, (глас) велий. Остальные слова, хотя и отсутствуют в лексикографических источниках, отражены в Национальном корпусе русского языка.

3.2.1. Среди таких слов выделяются историзмы, имеющие конкретное денотативное значение и обозначающие реалии новозаветной эпохи. Это прямые заимствования из греческого оригинала: Ин 13, 4 лентион (СП полотенце); Лк 7, 37 алавастр (СП алавастровый сосуд); Мф 27, 2 игемон (СП правитель); Мф 2, 11 ливан (СП ладан) и славянское слово, употребленное в Мф 20, 2, - neнязь (СП динарий).

Видимо, данные лексемы, обозначающие в евангельском тексте конкретные исторические реалии, не вошли в систему русского язы- 
ка, поэтому и отсутствуют в соответствующих словарях. Тем не менее, согласно данным корпуса, они используются в текстах: слова алавастр (5 вхождений), игемон (34), пенязь (4), ливан (5) употребительны в художественной литературе - в произведениях М.А. Булгакова, С.Н. Булгакова, Н.А. Полевого, Ф.В. Булгарина, Д.С. Мережковского, И.А. Бунина. Слово лентион функционирует как церковный термин, обозначая деталь облачения, и встречается в труде С.А. Диомидова «Указатель порядка архиерейских служений» (1915).

3.2.2. Бо́льшая часть слов рассматриваемого пласта - это лексемы, состоящие из понятных и употребительных корней и аффиксов, сочетание которых, однако, не характерно для русского языка, что и обусловило отсутствие таких слов в рассматриваемых лексикографических источниках. Приведем характерные примеры:

Мк 4, 47 урезать (СП отсечь); Лк 7, 38 созади (СП позади); Мк 5, 43 сведать (СП знать); Лк 5, 26 преславный (СП чудный); Лк 1, 2 исперва (СП с самого начала); Лк 11, 7 извнутрь (СП изнутри); Ин. 16, 2 возмнить (СП думать); Мф 5, 20 избыть (СП превзойти); Мф 25, 29 преизбыть (СП приумножиться); Ин 5, 35 светение (СП свет); Лк 8, 16 свещник (СП подсвечник); Мк 9, 29 изыти (СП вый$m u)$. Все приведенные слова зафиксированы в Национальном корпусе русского языка (то есть они, хотя и не закрепились в системе языка, все же встречаются в текстах).

Свещник (9) ${ }^{6}$. В значении «подсвечник» употребительно в художественной, богослужебной и богословской литературе: Ставится свешник с зажженною свечею (С.А. Диомидов «Указатель порядка архиерейских служений», 1915); ...и не угасал свещник ее всю ночь (Ф.И. Буслаев «Идеальные женские характеры Древней Руси», 1858). В том же значении употреблено в ПКП.

Преизбыть (8). Встречается в художественных и богословских произведениях: Пизонский видел, что на нашей просторной земле ... еще нетронутого добра будет $и$ преизбудет на всякую плоть (Н.С. Лесков «Котин доилец и Платонида», 1890); ...нужно верить в силу добра, которое преизбудет лишь в свободе (прот. Георгия Флоровский «Пути русского богословия», 1936). Для всех контекстов характерна аллюзия на евангельский текст - Мф 25, 29, в котором и употребляет данное слово Победоносцев (ибо имущему дано будет и преизбудет). Во всех контекстах слово имеет значение «умножится, будет больше».

Созади (24). Встречается в художественной и богослужебно-богословской литературе: Ей созади ветерок попутный дунул (Б.В. Шергин «Волшебное кольцо», 1930); прочие священники идут созади архиерея (С.А. Диомидов «Указатель порядка архиерейских служений», 1915). Во всех контекстах имеет значение «сзади, позади».

Светение (3). Употребляется в произведении Н.С. Лескова «Запечатленный ангел» (1873): ...Марой мог видеть около Луки светение, которое принял за ангелов; Со мною не было фонарей. - Откуда же светение? Кроме того, встречается в произведении митр. Антония (Блума) со ссылкой на письма свт. Феофана Затворника: И есть несколько писем святого Феофана Затворника ... о том, что есть естественное светение, когда нам делается внутренне тепло и как бы светится правда в нас... (Митр. Антоний (Блум) «Я хочу поделиться с вами всем, что накопилось», 1998). Во всех контекстах, как и в ПКП, слово имеет значение «свечение» (излучение света).

Сведать (34). Встречается в художественных произведениях Д.С. Мережковского, П.И. Мельникова-Печерского, Н.С. Лескова. Всегда имеет значение «узнать»: Бог мне помог об этом сведать (Д.С. Мережковский «Петр и Алексей», 1905).

Исперва (18). Встречается в текстах С.А. Есенина, В.С. Соловьева, В.В. Крестовского, митр. Филарета (Дроздова). Во всех контекстах имеет значение «сначала, сперва»: Таковым оно [христианство] и явилось исперва (В.С. Соловьев «Оправдание добра», 1899).

3.2.3. Отдельную группу составляют слова, которые можно назвать собственно архаизмами (они исчезли из словарей, но продолжают употребляться как стилистически маркированные, что отражено в материалах корпуса). По количеству слов данная группа сопоставима с предыдущей. Приведем наиболее характерные примеры: 
Лк 17, 12 сретить (СП встретить); Мф 23, 29 зиждет (СП строит); Мф 7, 11 кольми паче (СП тем более); Лк 12, 52 отселе (СП отныне); Мф 6, 6 клеть (СП комната); Ин 4, 11 студенеи (СП колодезь); Ин 13, 38 петел (СП петух); Мф 25, 30 неключимый (СП негодный); Лк 6, 7 назирать (СП наблюдать); Мк 16, 5 одеянный (СП облеченный).

Охарактеризуем использование некоторых приведенных слов в корпусе.

Кольми паче (153). Широко употребляется в текстах Д.С. Мережковского, Л.Н. Толстого, Ф.М. Достоевского, А.К. Толстого и др. Во всех контекстах, как и в ПКП, имеет значение «насколько больше».

Одеянный (5 в основном корпусе, 8 в поэтическом). В основном корпусе слово встречается в произведениях В.В. Вересаева, В.С. Соловьева (всегда в контекстах, посвященных описанию древних времен), у М.Е. Салтыкова-Щедрина. В поэтическом корпусе зафиксировано в стихотворениях Ф.И. Тютчева («Одеянный блистательной зарею», 1816), П.П. Ершова (одеянный лучами «Послание другу», 1836), Б.Ю. Поплавского (одеянный иветами «Жалость», 1923).

Петел (13 в основном корпусе, 56 в поэтическом). Употребляется в художественных текстах А.П. Чехова, К.А. Федина, Б.А. Лавренева, Г.П. Данилевского, Н. Клюева, Б.Ю. Поплавского. Во многих контекстах дана отсылка к евангельскому сюжету (Мф 26, 74) об отречении Петра: Но в ночи кукарекнет петел, как назад две тысячи лет (Н.Клюев «Поселиться в лесной избушке», 1919). В ПКП в параллельных контекстах наряду с данным словом употребляется и существительное nетух (Мф 26, 74; Ин 18, 27).

Зиждет (25 в основном корпусе и 36 в поэтическом). Используется в художественных, философско-богословских текстах Ф.Ф. Зелинского, Ф.М. Достоевского, А.И. Гончарова, еп. Игнатия (Брянчанинова), Иоанна Кронштадтского. Практически во всех контекстах функционирует в сочетании с абстрактными существительными (зиждет доброту, братство, язык). В ПКП встречается в Мф 23, 29 (Горе вам, книжники и фарисеи, лицемеры, что зиждете гробницы пророкам...). Не случайно слово употреблено в сочетании с существительным, имеющим конкретное значение (гробница): по-видимому, в данном контексте высокий стиль глагола подчеркивает нелепость лицемерной, внешней праведности фарисеев.

3.2.4. В исследуемом переводе можно выделить группу семантических архаизмов (устаревших значений некоторых слов): например, в ПКП (Ин 10, 35) употребляются глагол paзорить (ся) в значении 〈нарушить, нарушиться» (СП нарушиться), глагол предать в значении «передать» (СП поручить); при переводе Лк 21, 11 использовано существительное страхование в значении «ужас, нечто пугающее» (СП ужасные явления) и др. Данные слова зафиксированы в СУ, но значения, в которых они употреблены в ПКП, в нем не отражены. В текстах корпуса тем не менее представлены именно те лексико-семантические варианты, которые использует Победоносцев.

Pазорить. В сочетании с абстрактными существительными отмечено в произведениях Г. Флоровского (разорить заповедь), Н.К. Гудзия (разорить веру), Иоанна Кронштадтского (разорить Церковь). В приведенных контекстах, так же, как и в ПКП, имеет значение «не соблюсти, нарушить».

Предать. Глагол в большинстве случаев употребляется метафорически, с абстрактными существительными (предать забвению, предать огню, предать смерти) или в значении «обмануть, изменить». В некоторых контекстах реализует то же значение, что и в ПКП («передать»): например, в «Капитанской дочке» А.С. Пушкина: Пугачев предал им свою наложнииу.

Страхование. В текстах корпуса используется в основном как юридический термин (с таким же значением присутствует в СУ). В некоторых контекстах имеет то же значение, в котором употреблено в ПКП («страшное явление»), например, в произведениях Игнатия (Брянчанинова), в «Русской истории» Н.И. Костомарова: в Москве великое страхование, город затворяют рано вечером $и$ поздно утром отворяют.

3.2.5. К.П. Победоносцев употребляет в переводе такие слова из церковнославянского текста, которые, хотя и не зафиксированы в словарях, однако, согласно данным корпуса, часто используются в художественной и богословской литературе, но не самостоятельно, а в составе цитат из библейских или бого- 
служебных текстов. Такие слова можно условно назвать «цитатными» словами: они знакомы и понятны носителям русского языка именно благодаря известным цитатам, в составе которых они использованы и воспроизводятся. Приведем наиболее характерные примеры.

Вскую. Слово широко употребляется в художественных текстах Б.Л. Пастернака, В.Г. Короленко, Д.С. Мережковского, М. Горького, В.Я. Шишкова в составе цитат из евангельского повествования (Мф 27, 46) о крестной смерти Христа: Боже мой! Вскую мя еси оставил, из известных библейских и богослужебных текстов (псалмы 2 и 41, канон Богородице и на Лазареву субботу: Вскую шаташася языцы и людие поучишася тшетным (Пс 2, 1); Вскую печалуеши, душе... (Пс 41, 6); Вскую мя отринул еси от лииа Твоего (5 песнь канона на Лазареву субботу). Данные цитаты представлены в текстах указанных авторов дословно или с небольшими изменениями: Вскую мя оставил еси... - сказал он вдруг (В.Г. Короленко «Слепой музыкант», 1886-1898); Вскую шаташася, - стареи произносил слова эти каким-то загадочным голосом (В.Я. Шишков «Емельян Пугачев», 1939-1945); Вскую отринул мя еси от лииа Твоего, свете незаходимый (Б.Л. Пастернак «Доктор Живаго», 1945-1955).

Велий. Употребляется, в основном, в цитатах из богослужебных текстов: Кто Бог велий, яко Бог наш (великий прокимен, Пс 76); Велий еси Господи, и чудна дела Твоя (из чина Крещения). Встречаются в произведениях Мельникова-Печерского: Дьякон Мемнон во всю мочь распевал великий прокимен первого гласа: «Кто Бог велий, яко Бог наш» («На горах», 1881), Никифорова-Волгина: Священник читал молитву "Велий еси Госпо$\partial u$, и чудны дела Твоя...» («Крещение», 1938).

Oтроча. Употребляется в художественной литературе в составе цитат из Кондака Рождеству Христову, из евангельских текстов о царствии Божием (Лк, 18, 17; Мк 10, 9), о Рождестве Христовом (Мф 2, 13): Великий бо заутра праздник - родится Отроча младо, предвечный Бог (Е.А. Гагарин «Поездка на святки», 1945-1948); Иже аще не приимет иарствия божия, яко отроча, - не имать внити в не (М. Горький «Жизнь Матвея Ко- жемякина», 1910); Востав пойми отроча и Матерь его... (А.П. Чехов «Мужики», 1897).

Внити. Употребляется в составе цитат из евангельского текста о царствии Божием (Мк 10, 15), из текста песнопения вечерни первой седмицы Великого поста: Изринувшеся из рая, воздержанием страстей потщимся внити (Б.Л. Пастернак «Доктор Живаго», 1945-1955). Встречаются контексты, содержащие аллюзию на известные богослужебные тексты, как, например, в произведении А.Ф. Писемского «Люди сороковых годов» (1869): В воображении Павла вдруг представился чертог Господа и та светлая одежда, которую надобно иметь, чтобы внити в него (отсылка к тексту великопостного песнопения «Чертог Твой вижду, Спасе мой, украшенный, и одежды не имам да вниду вонь...»).

3.3. Третий пласт составляют такие слова (словоформы ${ }^{7}$ ), заимствованные из церковнославянского текста, которые не отражены ни в СУ, ни в текстах Национального корпуса русского языка. Мы выявили 15 таких слов и разделили их на группы.

Слова-термины:

Ин 12, 3 литра (СП фунт); Мф 9, 9 мытница (СП сбор пошлин); Мк 15, 16 спира (СП полк); Мф 21, 7 жребя (СП молодой осел).

Слова с нехарактерным оформлением корня:

Мф 13, 58 неверствие (СП неверие); Мк 7, 18 неразумливый (СП непонятливый); Мф 13, 21 привременный (СП непостоянный); Ин 16, 23 воспросить (СП спросить).

Слова, употребленные без характерного для них префикса:

Ин 17, 19 свящу (СП посвяшу); Мф 22, 5 небрегши (СП пренебрегши); Ин 21, 18 пояшет (СП препоямет); Мк 8, 11 стязаться (СП спорить).

Сложные слова:

Мф 27, 39 мимоходящие (СП проходящие); Мк 7, 22 студодеяние (СП непотребство); Лк 6, 1 второпервая (суббота) (СП первая по второмдне).

Из выделенных слов шесть употреблены в указанных контекстах в переводе Жуковского: мытница, литра, спира, неразумливый, мимоходящие, второпервая. Воз- 
можно, Победоносцев оставил в своем переводе данные слова именно с опорой на перевод Жуковского (подробно об этом см.: [Реморова, 2016]), с которым был знаком и о котором отзывался положительно [Победоносцев, 2000, с. II].

Слово жребя, употребленное Победоносцевым, - это редкий пример не стилистического, а смыслового отличия от СП, в котором данное слово переведено как молодой осел. На наш взгляд, Победоносцев сохранил церковнославянский вариант, поскольку он используется в текстах и песнопениях, звучащих во время богослужения, посвященного празднику Входа Господня в Иерусалим (вербное воскресенье). Например, в тексте кондака (На престоле на небеси, на жребяти на земли носимый, Христе Боже...), в отпусте (Иже на жребяти осли сести изволивый...).

К.П. Победоносцев стремился создать такой перевод Евангелия, «который не тревожил бы уха, знакомого с гармонией церковного чтения» [Победоносцев, 2000, с. II]. Данный переводческий принцип автора и объясняет основную особенность словарного состава перевода: поскольку он был создан для людей, живших в православной богослужебной традиции, в нем максимально сохранен словарный состав литургического церковнославянского текста. При этом Победоносцев не просто переносит церковнославянскую лексику в текст своего перевода, а производит тщательный отбор языковых средств и, как показывает собранный материал, использует в основном те лексемы, которые были употребительны в определенных текстах языка его эпохи.

Некоторые современные исследователи считают перевод Победоносцева неудачным и упрекают автора в искусственном соединении в одном тексте русского и церковнославянского начал: «В своем переводе Победоносцев не замечает существенных недостатков. Он не чувствует, что насильственное сталкивание двух разнородных языковых структур в одном тексте сильно затрудняет, а порой даже искажает самый смысл Священ- ного Писания» [Грехнева, Миркина, 2000, c. 413]. Далее в подтверждение своей позиции авторы без комментариев приводят несколько отрывков из перевода, содержащих в том числе слова страхование, глагол и другие подобные им лексемы, которые, как выявлено в результате проведенного нами исследования, во времена Победоносцева употреблялись несколько иначе, чем в русском языке конца XX века. При оценке перевода авторы, по-видимому, экстраполируют свое языковое восприятие на текст начала XX века, что, на наш взгляд, является методологической ошибкой, и потому их оценка перевода, выполненного К.П. Победоносцевым, не может претендовать на объективность.

Однако существуют документальные свидетельства того, что перевод Победоносцева был востребован современниками, являлся актуальным для некоторой части российского общества. Так, поэт, великий князь К.К. Романов 8 апреля 1915 г. писал А.Ф. Кони «В моей библиотеке нашелся перевод 4-х евангелистов, исполненный К.П. Победоносцевым, и я смогу послать вам эти книги. <... Я бы пошел еще далее Победоносцева, приближаясь в переводе к церковнославянскому тексту» (цит. по: [Матонина, 1994, с. 222]).

Перевод Победоносцева является предпочтительным и для некоторых современных филологов (см., например: [Роднянская, 1997, c. 86$)$.

Исследуемый текст представляет интерес не только как веха в истории формирования языка русской Библии, но и как уникальный памятник истории русского литературного языка конца XIX - начала XX в., открывающий целый пласт лексики, которая не была отражена в словарях, но при этом широко использовалась в художественных и богословских текстах известных авторов.

\section{ПРИМЕЧАНИЯ}

${ }^{1}$ В 2000 г. перевод репринтно переиздан Российским Библейским Обществом в Санкт-Петербурге: Новый Завет в переводе К.П. Победоносцева. Репринтное воспроизведение издания 1906 г. СПб., 2000.

2 Лексические единицы приводятся в упрощенной графике. 
3 Знаменитый поэт К.К. Романов, выражая свое одобрение перевода, выполненного Победоносцевым, в письме к А.Ф. Кони от 8 апреля 1915 года, писал: «слово искони в первых же стихах 1-й главы от Иоанна вполне могло бы быть сохранено без изменения» (цит. по: [Матонина, 1994, с. 222]).

${ }^{4} \mathrm{~B}$ большинстве случаев слово востать употребляется в ПКП именно в таком написании (с одной буквой $c$ ). Встретилось лишь три случая употребления этого глагола с двойной $c c$, всегда с разным значением: «бунтовать» (Мф 24, 7: восстанет народ на народ), «воскреснуть» (Лк 9, 7: Иоанн восстал из мертвых), «восстановить» (Мф 22, 24: восставит семя брату своему).

${ }^{5}$ В СП слово чадо употребляется только в обращении Христа к исцеленному человеку: Дерзай, чадо! Прощаются тебе грехи твои (Мф 9, 2). Во множественном числе всегда употребляется слово дети.

${ }^{6}$ В скобках приводится общее количество вхождений слова в корпусе. При анализе материала мы выбирали только те контексты, которые относятся к периоду 1820-1920-х гг.

${ }^{7}$ Некоторые слова из данной группы для наглядности мы приводим в том виде, как они употреблены в ПКП, а не в начальной форме.

\section{СПИСОК ЛИТЕРАТУРЫ}

Винокур Г. О., 2010. Избранные труды по языкознанию и культуре речи. М. : Изд-во ЛКИ. 232 с.

Глинский Б. Б., 2004. Константин Петрович Победоносцев (Материалы для биографии) // Великая ложь нашего времени. М. : Развитие духовности, культуры и науки. С. 3-45.

Глубоковский Н. Н., 1892. Общие указания по вопросу об исправлении славянского и русского переводов Нового Завета и замечания на славяно-русский текст Евангелия от Матфея; Евангелия от Марка; Евангелия от Луки; Евангелия от Иоанна (РНБ. Ф. 194. Оп. 1. Ед. хр. 55. 1892 г.).

Грехнев М. В., Миркина М. А., 2000. К вопросу о литературном творчестве К.П. Победоносцева // Нестор : ежеквартальный журнал истории и культуры России и Восточной Европы. № 1. С. 405-416.

Долгушин Д. В. (священник), 2008. Новый Завет в переводе В.А. Жуковского: история создания и публикации // Новый Завет Господа нашего Иисуса Христа. Перевод В.А. Жуковского / под ред. Ф. З. Кануновой, И. А. Айзиковой и свящ. Д. Долгушина. СПб. : Дмитрий Буланин. С. 408-447.

Емельянова О. Н., 2003. Стилистическая помета // Стилистический энциклопедический сло- варь русского языка / под ред. М. Н. Кожиной. М. : Флинта Наука. С. 444- 447.

Матонина Э., 1994. Баловень судьбы. Великий князь Константин Константинович Романов в письмах и воспоминаниях // Новый мир. № 4. С. 190-223.

Победоносцев К. П., 1892. Об исправлении русского перевода книг Священного Писания // Прибавления к церковным ведомостям, издаваемым при Святейшем Правительствующем Синоде. № 33. СПб. : Син. тип. С. 1129-1130.

Победоносцев К. П., 2000. Предисловие // Новый Завет в переводе К.П. Победоносцева. СПб. : Российское библейское общество. C. I-VI. [Репр. воспр. изд. 1906].

Реморов И. А., 2003. Формирование языка Синодального перевода Нового Завета (на материале редакторской правки митрополита Филарета (Дроздова)) : автореф. дис. ... канд. филол. наук. Томск. 25 с.

Реморова Е. Е., 2016. Переводы Четвероевангелия, выполненные В.А. Жуковским и К.П. Победоносцевым: две реализации одного подхода // Вестник Новосибирского государственного университета. Серия: История, филология. Т. 15, № 9. С. 140-147.

Роднянская И., 1997. Язык православного богослужения как препятствие к раскультуриванию современной России // Литературная учеба. № 5-6. С. 86-93.

\section{ИСТОЧНИКИ И СЛОВАРИ}

Национальный корпус русского языка : [сайт]. URL: http://www.ruscorpora.ru/.

Новый Завет в переводе К.П. Победоносцева, 2000. СПб. : Российское библейское общество. 629 с. [Репр. воспр. изд. 1906].

Словарь церковнославянского и русского языка, составленный Вторым отделением императорской Академии наук : в 2 кн. СПб. : Изд-во СПб. ун-та, 2001. Кн. 1 : А-Н. 8, ХХІІ, 415, 471 с. ; Кн. 2 : О-Я. 589, 487 с. [Репр. изд. публикации 1847 г.].

Словарь языка Пушкина : в 4 т., 1956-1961 / гл. ред. акад. В. В. Виноградов (отв. ред.) и др. М. : ГИС, 1956-1961.

$C У$ - Толковый словарь русского языка : в 4 т. / под ред. Д. Н. Ушакова. М. : Сов. энцикл. : ОГИЗ, 1935-1940.

\section{REFERENCES}

Vinokur G.O., 2010. Selected Works on Linguistics and Speech Culture. Moscow, Izd-vo LKI. 232 p. (in Russian). 
Glinskiy B.B., 2004. Konstantin Petrovich Pobedonostsev (materials for the biography). Velikaya lozh nashego vremeni. Moscow, Razvitie dukhovnosti, kultury i nauki Publ., pp. 345. (in Russian).

Glubokovskiy N.N., 1892. The general instructions on the amendments of the Russian and Slavonic New Testament translations and the notes to the slavonic-Russian text of the Gospel of Matthew, Mark, Luke, John. RNB, F. 194, Op. 1, Ed. khr. 55. (in Russian).

Grekhnev M.V., Mirkina M.A., 2000. On the Literary Creations of K.P. Pobedonostsev. Nestor: ezhekv. zhurn. istorii i kultury Rossii $i$ Vost. Evropy. Saint Petersburg; Kishinev, no. 1, pp. 405-416. (in Russian).

Dolgushin D.V. (priest), 2008. The New Testament: translation by V.A. Zhukovskiy: the history of creation and publication. Novyy Zavet Gospoda nashego Iisusa Khrista. Perevod V.A. Zhukovskogo. Saint Petersburg, Dmitry Bulanin Publ., pp. 408-447. (in Russian).

Emelyanova O.N., 2003. The Stylistic note. Kozhina M.N., ed. The Stylistic Encyclopedic Dictionary of the Russian Language. Moscow, Flinta Publ.; Nauka Publ., pp. 444-447. (in Russian).

Matonina E., 1994. A Favourite of the Fate. Grand Duke Konstantin Konstantinovich Romanov in the Letters and Memoirs. Novyy mir, no 4, pp. 190223. (in Russian).

Pobedonostsev K.P. 1892. About amendments of the Russian translation of the Holy Scripture. Pribavleniya $k$ tserkovnym vedomostyam, izdavaemym pri Svyateyshem Pravitelstvuyushchem Sinode. Saint Petersburg, Sin.tip., 1892, no. 33, pp. 1129-1130. (in Russian). Pobedonostsev K.P., 2000. The preface. Novyy Zavet v perevode K.P. Pobedonostseva. Saint Petersburg,
Rossiyskoe bibleyskoe obshchestvo, pp. I-VI. [Reprint 1906]. (in Russian)

Remorov I.A., 2003. The creation of the language of Synodal New Testament Translation (based on the editorial corrections by Metropolitan Philaret (Drozdov). Cand. philol. sci. abs. diss. Tomsk, 25 p. (in Russian).

Remorova E.E., 2016. The Gospel's translations into Russian by V.A. Zhukovskiy and K.P. Pobedonostsev: Two Versions of the Same Approach. Vestnik NGU, Ser: Istoriya, filologiya, vol. 15, no. 9, pp. 140-147. (in Russian).

Rodnyanskaya I. 1997. The language of the Orthodox divine service as an obstacle for disculturisation of modern Russia. Literaturnaya ucheba, no. 56, pp. 86-93. (in Russian).

\section{SOURCES AND DICTIONARIES}

National Corpus of the Russian Language. URL: http:// www.ruscorpora.ru/. (in Russian).

The New Testament: translation by K.P. Pobedonostsev, 2000. Saint Petersburg, Rossiyskoe bibleyskoe obshchestvo Publ., 629 p. [Reprint, 1906]. (in Russian).

The Dictionary of Church-Slavonic and Russian Languages. In 2 books, 2001. Saint Petersburg, Izd-vo SPb. un-ta. Book 1: A-N. 8, XXII, 415, 471 p.; Book 2: O-Ja. 589, 487 p. (in Russian).

Vinogradov V.V., ed. (et al.) The Dictionary of Pushkin's Language. In IV vols., 1956-1961. Moscow, GIS Publ.

Ushakov D.N., ed. Explanatory Dictionary of Russian Language. In IV vols., 1935-1940. Moscow, Sovetskaya entsiklopediya Publ.; OGIZ Publ. (in Russian).

\section{Information about the Author}

Elena E. Remorova, Postgraduate Student, Department of Ancient Languages, Novosibirsk State University, Pirogova St., 1, 630090 Novosibirsk, Russia, e.remorova@gmail.com, http://orcid.org/00000003-3413-0850

\section{Информация об авторе}

Елена Ефимовна Реморова, аспирант кафедры древних языков, Новосибирский государственный университет, ул. Пирогова, 1, 630090 г. Новосибирск, Россия, e.remorova@gmail.com, http://orcid.org/0000-0003-3413-0850 